ks. Edward Sienkiewicz

Uniwersytet Szczeciński

DOI: 10.15290/std.2015.01.14

\title{
BYT LUDZKI W KONTEKŚCIE WSPÓŁCZESNEGO SPORU O ROZUMIENIE NATURY I KULTURY CZŁOWIEKA
}

\section{HUMAN EXISTENCE IN THE CONTEXT OF CONTEMPORARY DISPUTE ABOUT THE UNDERSTANDING OF HUMAN NATURE AND CULTURE}

Modern dispute about the understanding of culture and nature is rich in tradition and dates back to ancient Greek sophists. However, in the modern era we observe a radicalization of positions. This is caused by superficial understanding of both the nature and culture, what matters is the narrow empiricism or extreme idealism. In addition, there is the absence of a human problem in this dispute, which is supported by anthropology practiced today within the framework of specialized and narrow detailed disciplines without the possibility of synthesis. An offer to solve this dispute, having sometimes the nature of the conflict, is a subjective nature of culture, allowing to reconcile man's relationship with nature and everything that cannot be brought only to this dimension. The best evidence of this solution proves to be a Christian personalism, which does not overlook any of the essential dimensions of human existence. Besides the complex structure of the human being - what best describes the concept of a person - it applies both to the material and the spiritual world, providing thus a foundation in resolving the dispute over the understanding of culture and human nature. The ultimate criterion remains the event of the Incarnation, which is appropriate to claim an objective criterion of reality - "I am the truth" (Jn 14,6), shedding light on the human understanding; his secret and mystery. The value of culture is evaluated from the point of view 
of the objective truth, which also remains a key reference within the meaning of nature and its relationship to human activity.

Key words: nature, culture, truth, man, person, mystery, naturalism, idealism, personalism, anthropocentrism, biological reductionism, post-modernism, civilization, species, nature, identity.

Spór o rozumienie natury i kultury nie jest bynajmniej problemem tylko naszych czasów. Ma on swoją bogatą i złożoną historię. Niemniej obecnie zdaje się przybierać dość ostrą formę, co uwarunkowane jest głównie radykalizującymi się stanowiskami jego uczestników i dość jednostronnym rozumieniem zarówno natury jak i kultury człowieka. Przy czym antropologiczne zaakcentowanie podjętej w tym artykule kwestii nie wynika z jakiegoś niedopatrzenia, mogącego podpadać pod zarzut tautologii. Innymi słowy, mówienie na temat natury oraz kultury z pominięciem problemu człowieka; tego wszystkiego, co jest w nim najistotniejsze - choć właśnie taka postawa charakteryzuje, niestety współczesne zainteresowanie wspomnianymi wymiarami - trzeba uznać za przynajmniej nierzetelne. Poza tym - jak to wyraźnie pokazuje doświadczenie - przysparzające coraz więcej problemów, trudnych do rozwiązania, i w zasadzie sprowadzających dyskusję na przysłowiowe manowce.

Już na wstępie zatem naszych rozważań pojawia się pytanie: dlaczego człowiek, tak bardzo wnikliwie interesujący się wszystkim, co go otacza, z czym wchodzi w relacje; od czego czuje się zależny i nad czym chce skutecznie zapanować, stał się dziś sam dla siebie tak mało wdzięcznym problemem w badaniu, choć wciąż nie przestaje być dla siebie intrygującą zagadką? Nie przestaje być również tajemnicą. Zanim spróbujemy odpowiedzieć na to pytanie i przez to - jak ufamy - rzucić nieco światła na zaostrzający się spór o rozumienie kultury oraz natury, może dobrze będzie uświadomić sobie, że mamy do czynienia z zagadnieniem bardzo złożonym. Po pierwsze nie możemy mówić o zupełnym braku zainteresowania człowiekiem, ale raczej o pewnym „klinczu” w formułowaniu na ten temat wyczerpujących koncepcji. I po drugie zainteresowanie wymiarem kultury i natury bardzo często traktuje się jako zastępczy temat rzeczywistości, której tak po prostu nie da się zostawić poza poznawczym działaniem człowieka. Zdaje się to być bardzo charakterystyczną cechą współczesnego zainteresowania człowiekiem, którego coraz rzadziej określa się wprost; przez jego wewnętrzną strukturę, istotę, coraz częściej opisując go przez to, co wprawdzie jest z nim jakoś związane, ale znajduje się na zewnątrz; w jakiejś relacji do niego. Nie zmienia to faktu, że zagadnienia kultury i natury, przez ich bliski i nierozerwalny związek z człowiekiem, przyczyniają się do lepszego zrozumienia bytu ludzkiego. Stąd na pytanie: kim jest człowiek? 
usiłuje się odpowiadać penetrując różne wymiary i dziedziny jego egzystencji, co nie zabezpiecza skutecznie przed oddalaniem się od koniecznej - przy próbie udzielenia odpowiedzi na takie pytanie - syntezy.

Rozwiązanie postawionego problemu postaramy się przeprowadzić $\mathrm{w}$ taki sposób, ażeby ukazać najbardziej charakterystyczne momenty zarysowanego sporu między rozumieniem natury i kultury. Wskazać ponadto największe niebezpieczeństwa, zwłaszcza tam, gdzie pojawiają się bardzo jednostronne i powierzchowne ujęcia, zarówno natury, jak i kultury człowieka, a także pewne nadzieje, jakie rodzą się w związku z tym sporem oraz nowe perspektywy. W tym celu wskazane będzie przynajmniej wspomnienie o najbardziej rozpowszechnionych dziś - nie unikając historii wszędzie tam, gdzie okaże się to potrzebne - stanowiskach $\mathrm{w}$ rozumieniu natury i kultury. Wreszcie postaramy się wskazać na jedynie słuszną podstawę rozwiązywania tegoż sporu, ukazując trudności, ale i możliwości, jakie pojawiają się w pytaniu o to, co człowieka w najgłębszym sensie określa oraz tłumaczy. Człowieka, którego zarówno bez natury jak i kultury trudno rzetelnie opisywać, a tym bardziej definiować.

\section{Czym jest natura i dlaczego zainteresowanie nią powinno mieć charakter antropocentryczny?}

Właściwie sformułowanie tematu naszych rozważań dość jednoznacznie przesądza o antropologicznym ich charakterze. Tym niemniej nie usuwa to wszelkich wątpliwości, zwłaszcza kiedy weźmie się pod uwagę wspomniane, najbardziej rozpowszechnione dziś sposoby rozumienia natury i kwestie terminologiczne. Oczywiście zawsze możliwe jest i takie rozwiązanie, które nie musi się przejmować tym, co najczęściej powtarzane, a zwłaszcza modne, szczególnie kiedy chce się dojść do tego, co prawdziwe. Jak już wspominaliśmy, spór o rozumienie natury i kultury ma swoją historię, sięgającą starożytnych sofistów. Niestety - w odróżnieniu od naszych czasów, brzemiennych wręcz w zaangażowanie weń licznych i rozmaitych środowisk, na bardzo różnych poziomach - w starożytności problem ten nie został podjęty, choć i wówczas wyraźnie zaznaczała się opozycja wobec wszelkich prób pogodzenia tego, co od człowieka niezależne, co go niejako kształtuje, z tym, co właśnie tworzy i kształtuje człowiek ${ }^{1}$. Osią zatem tego sporu i to już od czasów helleńskich mędrców, pozostaje to, co w człowieku niezmienne, przez co jest on, w pewnym sensie, nieodwracalnie zdeterminowany i to, co może być przez niego kształtowane, modelowane, według różnych oczekiwań i zapatrywań. W poszukiwaniu

1 Z. Hajduk, Natura, w: Encyklopedia katolicka, t. XIII, E. Gigilewicz (red.), Lublin 2009, k. 805; W. Dłubacz, Natura czy naturalizm?, w: Substancja, natura, prawo naturalne, Lublin 2006, s. 205-221. 
konkretnego osadzenia zarysowanego sporu obecnie, ponieważ to nas najbardziej interesuje, poprzestaniemy na przypomnieniu najbardziej wyrazistych stanowisk, które w podobnym sensie wpływają na wyrazistość - ostrość interesującego nas sporu ${ }^{2}$. Zwłaszcza, że przytaczanie rozwiązań z historii problemu, chociażby tych najważniejszych, rozszerzyłoby naszą refleksję do ram raczej nie do przyjęcia.

Jakie zatem są te najbardziej wyraziste stanowiska w związku z postawionym w tym artykule problemem, czyli w kontekście sporu o rozumienie najpierw natury? To po pierwsze, biologiczny redukcjonizm, według którego naturę rozumie się jako zakrojenie człowieka do jednego z etapów ewolucyjnego rozwoju gatunków, gdzie pozbawiony jest swojej wartości w porównaniu z nimi i wyjątkowości. Człowiek w takim ujęciu, to przede wszystkim wysoko wyspecjalizowany organizm żywy. Dalej, produkt oddziaływań ewolucyjnych. Wreszcie byt niewyróżniający się w sposób istotny spośród innych gatunków. Przedstawicielem takiego myślenia jest m.in. Edward Wilson, zajmujący się przez długi czas życiem mrówek i wyciągający wnioski co do wspólnego wszystkim istotom żywym procesu, regulującego wszelką zbiorowość, a więc i tę, która organizowana jest w oparciu o powstające struktury społeczne ${ }^{3}$. Co więcej, wpływającego, a nawet regulującego procesy kulturowe; decydującego o postawach i wyborach poszczególnych jednostek, wręcz całej zbiorowości:

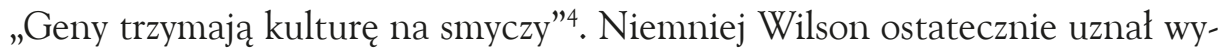
jątkowość i wyższość człowieka wobec innych gatunków na podstawie trzech specyficznie ludzkich cech: pamięci długotrwałej, myślenia symbolicznego oraz posiadania języka. Mimo to człowiek, nawet jako szczególnie rozwinięta cząstka świata przyrody, nadal pozostaje całkowicie do niego przypisany. Naśladowca radykalnych tez Wilsona - Peter Singer - domaga się przyznania i ochrony przez ONZ praw zwierząt ${ }^{5}$. Naturalizm P. Singera sprzeciwia się przyznawaniu człowiekowi większych praw niż zwierzętom z zasady. Podobnie jeśli chodzi o godność. Uważa on, że niektóre zwierzęta ją posiadają w przeciwieństwie do niektórych ludzi, którym należy jej odmówić ${ }^{\text {. }}$

2 A. Salamucha, Natura czy kultura? Wstępna charakterystyka sporu, w: Kultura wspótczesna a wychowanie czlowieka, D. Kubinowski (red.), Lublin 2006 s. 74.

3 E. O. Wilson, Socjobiologia, Poznań 2000; idem, Konsiliencja. Jedność wiedzy, Poznań 2002, s. 174; B. Szacka, Stowo wstępne, w: E. O. Wilson, O naturze ludzkiej, Warszawa 1987, s. 6.

E. O. Wilson, O naturze ludzkiej, s. 16.

5 P. Singer, Wyzwolenie zwierzat, tłum. A. Alichniewicz, A. Szczęsna, Warszawa 2004, s. 21-22.

6 Idem, O życiu i śmierci. Upadek etyki tradycyjnej, tłum. A. Alichniewicz, A. Szczęsna, Warszawa 1997, s. 241; idem, Etyka praktyczna, tłum. A. Sagan, Warszawa 2003, s. 9. 
Argumentacja usiłująca dowieść całkowitej przynależności człowieka do natury (biologii) podkreśla przede wszystkim podobieństwo w budowie anatomicznej człowieka i zwierząt, w procesach fizjologicznych i pewnych schematach zachowań. Nie wchodząc w szczegóły trudno nie dostrzec tu wyraźnej jednostronności, nawet swoistej determinacji w pomijaniu wszelkich jakościowych różnic. Poza tym wciąż nieprzezwyciężonego, pozytywistycznego rozumienia nauki oraz ludzkiej wiedzy, w którym wyznacznikiem pozostaje empiryzm. Niemniej wciąż aktualne jest pytanie o kompetencje empiryzmu w rozstrzyganiu problemu natury człowieka, zwłaszcza, że o kwestiach złożonych i wielowymiarowych, przedstawiciele tego kierunku chcą orzekać tylko na podstawie jednego wymiaru i jednostronnie rozumianego doświadczenia. Tak wielka jednak jednostronność i na tej tylko podstawie tworzone uogólnienia, wręcz obnażają wiele luk i niespójności. Usiłuje się je zastąpić określeniem „natury plastycznej”, podlegającej modyfikacjom i wychowaniu, co odsyła nas już do problemu kultury ${ }^{7}$, której w owej perspektywie naturalistycznej - jak pokazuje historia problemu - bynajmniej się nie gloryfikuje.

Innym stanowiskiem, najczęściej określanym i definiowanym przez wyraźną opozycję do powyższego, jest rozumienie natury jako wewnętrznego uposażenia człowieka, decydującego o jego odrębności od wszystkiego, co go otacza. W tym od innych form życia i gatunków. I poglądy takie pojawiły się już w starożytności. Wystarczy wspomnieć Platona, koncentrującego się na separowanej od materii idei i zachęcającego do gruntownego poznania swojej natury przez człowieka $^{8}$. Wiele jego rozstrzygnięć zostało poprzedzonych zainteresowaniem istotą człowieka mistrza Platona, czyli Sokratesa, odnoszącego swoją myśl do zagadnień etycznych. Platon, choć podkreślał trudność poznania natury idei, w niej widział podstawę istnienia wszystkiego innego; na niej wzorowanego? Nie umniejszając znaczenia różnych ujęć oraz koncepcji idealizmu w późniejszych wiekach, nierezygnujących z problemu natury, można tu jeszcze wspomnieć teorię Leibniza, utożsamiającego z Bogiem ideę dobra, później przez działalność człowieka zniszczonego. Po tej linii kroczy także często spotykana interpretacja biblijnego obrazu stworzenia z Księgi Rodzaju, które na początku „było dobre”, a później przez ludzką działalność, tę pierwotną dobroć

$7 \quad$ M. Ridley, Nature via Nurture (Genes, experience and what makes us human), London 2003.

$8 \quad$ Platon podzielił swój system na filozofię moralną, filozofię przyrody i filozofię rozumową. Przy czym filozofia przyrody była dla niego raczej teoretycznym rozważaniem. R. H. Popkin, A. Stroll, Filozofia, tłum. J. Karłowski, N. Leśniewski, A. Przyłęcki, Poznań 1994, s. 7-9.

9 Platon, Państwo, tłum. W. Witwicki, Kęty 2003, VII, 537 C. 
utraciło $^{10}$. Natura ludzka to stan pierwotny, coś co wyszło z rąk Twórcy i nie zostało jeszcze wypaczone ${ }^{11}$.

Przytoczone przykłady tylko potwierdzają nasze wcześniejsze stwierdzenie, że natura rozumiana jest generalnie na dwa sposoby: jako przyroda i jako istota człowieka.

\section{Podmiotowy charakter kultury i jej relacja do natury}

A czym jest kultura i jaki wpływ ma ona na człowieka w jego naturalnym uposażeniu, czyli w relacji do natury? Kultura (z łac. colere - 'uprawiać', 'dbać', 'pielęgnować', 'kształtować'), jest terminem wieloznacznym, pochodzącym od łac. cultus agri (uprawa ziemi), interpretowanym w różny sposób przez przedstawicieli różnych nauk, czego dowodem jest ponad 200 definicji kultury ${ }^{12}$. Kulturę można określić jako ogół wytworów ludzkich, zarówno materialnych, jak i niematerialnych - duchowych ${ }^{13}$, symbolicznych (takich jak wzory myślenia i zachowania) ${ }^{14}$. Najczęściej jednak rozumiana jest ona jako całokształt ducho-

10 J. Bednarski, Enkulturacja, w: Stowniketnologiczny, Z. Staszczak (red.), Warszawa-Poznań 1987 s. 75-77; W. J. Burszta, Antropologia kultury, Poznań 1998, s. 85 ; A. Posern-Zieliński, Akulturacja, w: Stownik etnologiczny, Z. Staszczak (red.), Warszawa-Poznań 1987 s. 16-19. Platon, Państwo, VI, 508 C, 509 A.

12 Pierwotnie termin 'kultura' wiązał się z uprawą roli, bądź hodowlą zwierząt i oznaczał przekształcanie naturalnego stanu zjawisk przyrody w stan bardziej użyteczny i przydatny człowiekowi. Pierwszy raz w nowym znaczeniu termin ten został użyty przez Cycerona, który w dziele Disputationes Tusculanae użył sformułowania cultura animi (uprawa umysłu) w celu określenia pierwszej w literaturze koncepcji filozofii: „Czymże bez ciebie bylibyśmy nie tylko my, ale czym byłoby w ogóle ludzkie życie? Tyś pozakładała miasta, ty rozproszonych ludzi powołałaś do życia społecznego, ty zespoliłaś ich między sobą najpierw przez wspólne osiedla, później przez małżeństwa, a wreszcie przez wspólnotę mowy i pisma. Tyś wynalazczynią praw, nauczycielką dobrych obyczajów i ładu." Od tamtego czasu termin 'kultura' zaczęto wiązać z czynnościami ludzkimi, które miały na celu doskonalenie, pielęgnowanie czy kształcenie. W ciągu wieków słowo to było coraz częściej używane przez filozofów, a potem i uczonych zajmujących się naukami społecznymi, aż w końcu rezultatem tego procesu stała się wieloznaczność terminu 'kultura'. T. Reroń, Kultura, w: Leksykon duchowości katolickiej, M. Chmielewski (red.), Kraków 2002, s. 457-458; R. Rogowski, Wiara a kultura w aspekcie antropologiczno-teologicznym, „Homo Dei” 79 (1980), 3, s. 211-218.

13 I. Wojnar, Humanistyczne intencje edukacji, Warszawa 2000, s. 136-137; J. Gajda, Antropologia kulturowa, cz. I, w: Wprowadzenie do wiedzy o kulturze, Toruń 2003, s. 87.

14 Johann Herder w XVIII wieku napisał w przedmowie do Myśli o filozofii dziejów: „Nie ma nic bardziej nieokreślonego niż słowo kultura”. Jakby na przekór tej opinii badacze kultury tworzyli wciąż nowe definicje, za każdym razem uwzględniając jakiś wycinkowy, konkretny punkt widzenia na kulturę. Ralph Linton podsumował te starania słowami: „Istotą wszelkiej definicji kultury jest bowiem to, że wybiera pewne aspekty całego pojęcia oznaczanego owym terminem i kładzie nacisk na nie kosztem innych aspektów. Nacisk 
wego oraz materialnego dorobku społeczeństwa. Również charakterystyczne dla danego społeczeństwa wzory postępowania, także to, co w zachowaniu ludzkim jest wyuczone, w odróżnieniu od tego, co jest naturalnie odziedziczone. Całość wiedzy na temat kultury próbuje badać kulturoznawstwo, choć można mówić o filozofii kultury, socjologii kultury, antropologii kultury, historii kultury. Nie bez znaczenia jest również etymologiczna bliskość terminu: cultura z cultus kult, co wskazuje także na bliskość religijnego kontekstu. Zwłaszcza, że uprawa roli przez wieki była uważana za rodzaj współpracy człowieka z Bogiem ${ }^{15}$, czego ślady znajdujemy chociażby w historii Kaina i $\mathrm{Abla}^{16}$. Dość istotne wydaje się przeciwstawienie kultury takim pojęciom, jak natura i cywilizacja ${ }^{17}$. $\mathrm{O}$ ile pierwsza miała na celu podkreślenie tego, co przez człowieka zastane, uwypuklające jego zależność od przyrody, to drugie określało sposób spożytkowania przez człowieka tego, co zastane, praktycznego wykorzystania tego $\dot{z}^{18}$.

Dobrze będzie pamiętać, że kultura ma przede wszystkim charakter podmiotowy. Tak więc „kulturalny jest człowiek” - on rozwija, tworzy kulturę, a nie „kulturalnie urządzony jest jego dom”, ponieważ wiszą tam ciekawe płótna; kulturalnie zagospodarowana ulica, plac... ${ }^{19}$. Przywołując etymologię, jako termin, zdaje się on bardziej nawiązywać do uprawy ziemi, niż budowy mostów, czy stadionów. Nie tracąc przy tym z oczu właściwego naszej epoce, tzw. postmodernizmu (określanego również jako współczesna forma sceptycyzmu) i właściwego mu relatywizowania kultury ${ }^{20}$, co jest bez wątpienia wielkim problemem, ale i poważnym zagrożeniem. To właśnie pod wpływem tego nurtu kulturę coraz częściej określa się jako zupełną dowolność w formułowaniu tez i lansowaniu określonych zachowań, czyli obojętność, a nawet sprzeciw wobec jakichkolwiek obowiązujących zasad, nienaruszalności kanonów. Poza tym jako

ten, a w konsekwencji także wartość definicji, będą zależały od tego, jaki szczególny cel definiujący miał na uwadze. Istnieje wiele możliwości definiowania kultury, a każda jest użyteczna w powiązaniu z dociekaniami określonego rodzaju”.

15 J. Skoczyński, Kultura, w: Stownik społeczny, B. Szlachta (red.), Kraków 2004, s. 614.

16 J. Ratzinger, Wiara - prawda - tolerancja. Chrześcijaństwo a religie świata, tłum. R. Zajączkowski, Kielce 2004, s. 78-79.

17 S. Kowalczyk, Kultura-pojęcie, w: Encyklopedia katolicka, t. X, A. Szostek (red.), Lublin 2004, k. 188.

18 T. Reroń, Leksykon duchowości katolickiej, s. 458; J. Kowalski, Kultura w integralnym rozwoju człowieka w świetle nauczania Jana Pawła II, w: Stużyć prawdzie i mitości, J. Kowalski (red.), Częstochowa 1984, s. 251-268.

19 S. Kowalczyk, Kultura - pojęcie, w: Encyklopedia katolicka, t. X, k. 190-191.

20 J. Skoczyński, Kultura, w: Stownik społeczny, s. 618; S. Kowalczyk, Kultura a religia, w: Encyklopedia katolicka, t. X, k. 196. 
zdecydowane odcinanie się od tradycji, historii problemu i powstałych w niej rozstrzygnięć. I to, im bardziej radykalnie, tym lepiej.

Daje się zatem zauważyć niejako nowa odsłona lub inny wymiar interesującego nas sporu o rozumienie kultury i natury. Otóż na wspomniane powyżej, pozytywistyczne - jak się okazuje - wciąż nieprzezwyciężone okrojenie rozumienia natury, co w równej mierze dotyczy także kultury (o czym poniżej), uzależniające jedną i drugą od biologii, nakłada się, związany z postmodernizmem relatywizm. W zasadzie nieuznający jakiegokolwiek uzależnienia i uwarunkowania. Próba formułowania, a tym bardziej systematyzowania rozwiązań czy też wniosków w związku z tym sporem (można go określić jako spór naturalizmu z ponowoczesnością), na pewno jest dziś przedwczesna i obciążona wielkim ryzykiem. Niemniej chodzi o problem bardzo istotny. Może się bowiem okazać, że dominacja empiryzmu w rozumieniu natury, której nie zdołały przez ponad dwieście lat przezwyciężyć inne, bardziej humanistyczne ujęcia, w tym związane z chrześcijańskim obrazem świata i człowieka, zostanie - jeśli nie usunięta - to bardzo wyraźnie zachwiana przez nurty relatywizujące, związane z ponowoczesnością, zaledwie w ciągu lat kilkunastu (o kilkudziesięciu raczej nie można jeszcze mówić). Oczywiście nie wynika to $z$ wartości propozycji, jaka zaczyna radykalnie „modelować” pojmowanie natury z punktu widzenia swoistego rozumienia kultury. Mamy bowiem do czynienia z gloryfikacją podważania i wręcz negowania jakichkolwiek wartości. Chodzi tu zatem o poważną słabość i głęboki kryzys naszej cywilizacji. Ale rozwijanie tego zagadnienia już zasadniczo wykracza poza postawiony w artykule problem.

Wracając jednak do naszego podstawowego sporu (o rozumienie kultury i natury), w czym ten wspomniany powyżej nie jest bynajmniej bez znaczenia, ponownie wróćmy do człowieka. Podobnie jak w kwestii natury, także i w kontekście kultury trzeba zapytać: jakie cechy odróżniają go od innych gatunków, stanowiąc jednocześnie jego wyjątkowość? Odpowiedzi, jak się okazuje są bardzo różne. Do wciąż znajdujących swoich zwolenników i trzeba powiedzieć, ciągle wywierających znaczący wpływ na rozumienie kultury, należą te - jak możemy je określić - bardzo naturalistyczne. Sprowadzające wręcz lub całkowicie uzależniające kulturę od natury; biologicznego zdeterminowania ${ }^{21}$. W ich ramach „tradycyjnie” kontestuje się obiektywną wyższość człowieka nad innymi gatunkami. Wychodząc z takiego stanowiska człowiekowi można przyznać jakąś wyjątkowość tylko z tego tytułu - jak twierdzą zwolennicy tego kierunku - że potrafi on skutecznie zachwiać, a nawet zniszczyć równowagę

21 W. Oniszczenko, Genetyczne podstawy ludzkich zachowan. Przegląd badań w populacji polskiej, Gdańsk 2005. 
świata przez swoje działanie (człowiek „największym szkodnikiem” w naturze i to przez swoją - jak mu się wydaje - kulturalną działalność) ${ }^{22}$.

Niemniej ciągle aktualne pozostają kwestie granicy między kulturą a naturą, którą jest bardzo trudno wyznaczyć. Poza tym spór o to, w jakim sensie można mówić o kulturze w rozumieniu ogólnym (ogólnoludzkiej) ${ }^{23}$, a w jakim tylko o konkretnych kulturach i w związku z tym o uogólnieniu oraz domniemaniu, jakie się w takiej sytuacji musi pojawić ${ }^{24}$. Z tym związana jest wieloznaczność kultury; rozumienie jej jako specyficzne dla gatunku ludzkiego wzory zachowań, uwarunkowanych genetycznie ${ }^{25}$. Poza tym jako opanowany mechanizm adaptacji do otoczenia przyrodniczego. Jakkolwiek rozumie się kulturę, w tym nurcie trudno postrzegać ją inaczej jak element natury (przyrody), gdzie kultura zostaje wchłonięta przez naturę lub trwale zdeterminowana przez nią. Skrajnym przypadkiem takiej zależności jest rozumienie kultury jako fenotypu rozszerzonego (R. Dawkins). Jednostką doboru naturalnego jest tutaj gen, a wszystkie zachowania organizmów żywych są zaprogramowane w celu multiplikowania własnych genów. Człowiek należy zatem trwale do świata zwierzęcego, biologicznego. Przy czym wyłaniają się dwa sposoby postępowania: zmierzające do okiełznania natury, którą pojmuje się jako amoralną i chce okiełznać niejako przez wychowanie (socjalizację). Zakładające jednak uwzględnianie w wychowaniu natury i podkreślające zwierzęce dziedzictwo, należącego do natury człowieka, którego wychowanie nie przezwycięża, ponieważ jest również procesem należącym do natury, nieprzeciwstawiającym się jej. Innym stanowiskiem - w kwestii granicy między kulturą a naturą - jest podkreślanie wręcz niemożliwości nie tylko definiowania, opisywania, ale nawet myślenia o naturze bez kultury, ponieważ jako taka po prostu nie istnieje ${ }^{26}$.

22 A. Grzegorczyk, Psychiczna osobliwość cztowieka, Warszawa 2003, s. 143; N. Wolański, Uniwersalizm jako podstawa cywilizacji europejskiej. Biologiczne $i$ cywilizacyjne aspekty uniwersalizmu, „Społeczeństwo Otwarte” 5 (1998), s. 21.

23 Mimo że nadal kulturę w sposób obiektywny postrzega się jako cały dorobek ludzkości, przekazywany z pokolenia na pokolenie, coraz częściej podkreśla się rozumienie kultury budującej zespól cech charakteryzujących poszczególnych ludzi. Odchodzi się również od obrazu kultury jako systemu zintegrowanego, co było właściwe antropologii minionego wieku. O. Woźniak, Dlaczego niektórzy ludzie odnosza sukces częściej niż inni?, „Przekrój Nauki” 1 (2008), s. 18; U. Hannerz, Powiazania transnarodowe. Kultura, ludzie, miejsca, tłum. K. Franek, Kraków 1996, s. 21; J. Kozielecki, Transgresja i kultura, Warszawa 1997, s. $179-185$.

24 I. Wojnar, Humanistyczne intencje edukacji, Warszawa 2000, s. 136-137; J. Gajda, Antropologia kulturowa, w: Wprowadzenie do wiedzy o kulturze, cz. I, Torun 2003, s. 87.

25 A. Salamucha, Natura czy kultura? Wstępna charakterystyka sporu, s. 74.

26 U. Hannerz, Powiazania transnarodowe..., s. 58; E. T. Hall, Poza kultura, Warszawa 1984, s. 23. 
W imię rzetelności naszego postępowania nie można nie dostrzegać tych propozycji, które dążą do odcięcia się od wielu stereotypów, ocenianych jako przeżytki w nowej rzeczywistości. Zachęcają one do otwarcia na nowe możliwości dające szansę na bogatsze egzystowanie, na postęp, w którym dostrzega się nie tylko sferę materialną ludzkiego życia, ale i „bogactwo duchowe”. Człowiek bowiem nie tylko tworzy kulturę, ale jest również przez nią kształtowany; przez poprzedzające go pokolenia i to, co niejako zastaje przychodząc na świat ${ }^{27}$. Sztywne trzymanie się dawnych wzorców postrzegane jest w tym nurcie jako prowadzące do degeneracji społecznej, zamykanie się na nowe idee, do społeczności ksenofobicznej, niezdolnej do przystosowania się do nowych warunków, które są faktem. Podyktowane jest to potrzebą bezpieczeństwa, ale jest to bezpieczeństwo złudne ${ }^{28}$. Znacznie bardziej rzeczywiste jest to, do którego dążymy przez osiągnięcie tożsamości społecznej ${ }^{29}$, jako rezultatu identyfikacji z określoną grupą, zbiorowością osób, związanych z nami jakimś podobieństwem. Niezależnie od tego, czy będą to liczne, różne tożsamości, czy coś w rodzaju jednej „tożsamości zbiorowej”, będzie to efektem funkcjonowania w kulturze, z którą się utożsamiamy. Na ten problem nakładają się niebezpieczeństwa związane $z$ globalizacją ${ }^{30}$. Otóż często traktuje się ją jako zagrożenie lokalnej różnorodności kulturowej, a w tym tożsamości. Stąd coraz częstsze są głosy w sprawie podtrzymywania i dowartościowywania lokalnych tradycji, traktowanych jako - w ich różnorodności - najcenniejszy skarb Europy, możliwy do zaoferowania całemu światu ${ }^{31}$.

\section{Człowiek jako podstawa w rozwiązywaniu sporu o rozumienie natury i kultury}

Zarysowany powyżej spór między naturą a kulturą, a właściwie przedstawione, najbardziej lansowane dziś stanowiska, zdają się nie gwarantować nie tylko rozwiązania interesującego nas problemu, ale również spotkania, które

27 J.Bednarski, Enkulturacja, w: Stowniketnologiczny, Z. Staszczak (red.), Warszawa-Poznań 1987, s. 75-77; W. J. Burszta, Antropologia kultury, Poznań 1998, s. 85; A. Posern-Zieliński, Akulturacja, w: Stownik etnologiczny, s. 16-19. 85.

28 E. T. Hall, Poza kultura, s. 134-135.

29 M. Szopski, Komunikowanie międzykulturowe, Warszawa 2005, s. 27.

30 J. Nikitorowicz, Globalizacja a kultura jednostki, w: Kultury tradycyjne a kultura globalna. Konteksty edukacji międzykulturowej, t. 1, J. Nikitorowicz (red.), Białystok 2001, s. 23-24.

31 L. Harris, Kosmopolityczne złudzenie, tłum. A. Romaniuk, „Res Publica”3 (2006), s. 152-160; M. Nussbaum, Patriotism and Cosmopolitanism, „Boston Review” 19/5 (1994), s. 157-159; W. Wosińska, Oblicza globalizacji, Sopot 2008, s. 337; A. Horbowski, Edukacja kulturalna jako system działan społeczno-wychowawczych, Rzeszów 2000, s. 25-26. 
daje nadzieję uczciwego dialogu. Przyczyna jest dość oczywista. Chodzi o brak podstawy takiego spotkania; o pomijaną rzeczywistość, której różne stanowiska i koncepcje dotyczą, ponieważ w sporach o to, co dotyczy człowieka, co go w najwyższym stopniu angażuje, jakoś przedziwnie konsekwentnie jest pomijany sam człowiek. Jak zwykle przyczyn tego stanu rzeczy jest wiele, ale bodajże najbardziej wyróżniającą się, choć niby niedostrzeganą, na pewno przemilczaną, jest swoista „naukowa bezradność”. Chodzi naturalnie o dziedziny wiedzy, które uznały się za najbardziej kompetentne w wyjaśnianiu rzeczywistości ludzkiego bytu, notabene odwołujące się tylko do jednego wymiaru tej rzeczywistości (empirycznego), co niejako samo przez się miało usprawiedliwiać lawinowe wręcz i błyskawiczne mnożenie się różnych dyscyplin naukowych, jeszcze szybciej oddalających się od siebie. Przestały one z czasem nie tylko uzgadniać ze sobą swoje wyniki, ale nawet je sobie komunikować. Doprowadziło to w końcu do zniesienia choćby bardzo kruchej płaszczyzny spotkania, naukowej dyskusji, nie mówiąc już o jakiejkolwiek syntezie. Bez tej jednak człowiek musi jawić się jako bardzo różnie rozumiany, gdzie różnice jest trudno pogodzić, a nawet ze sobą skonfrontować, co tylko pogłębia i uwyraźnia wspomnianą „naukową bezradność"32. Do braku pełnej, zintegrowanej wiedzy o człowieku zaczęli się przyznawać głośno także ci, którzy najchętniej ze swojego „naukowego” słownika bardzo chętnie wyrzuciliby takie terminy jak „tajemnica” i „prawda”33.

Czy rzeczywiście jesteśmy zdani na taką bezradność i co za tym idzie „naukową porażkę" w sprawie sporu o rozumienie kultury i natury, ponieważ wyraźnie na manowce - w wydaniu współczesnych nauk - zszedł problem, który jako jedyny może być tego podstawą, czyli człowiek? Na pewno nie jesteśmy zdani na uciekanie od tajemnicy i prawdy, przede wszystkim w nauce! W tym kontekście natura i kultura człowieka to jedynie dwa aspekty rzeczywistości ludzkiej, które oderwane od niej i jeszcze zwracane przeciwko sobie, nie mogą stanowić nic więcej poza pozorami dialogu i podkreślaniem braku jakichkolwiek podstaw do rozwiązywania sporu. Przypomnijmy, sporu toczącego się od starożytności, którego już wówczas nikt nie ważył się odrywać od pytania o najgłębszą istotę człowieka; kim jest? Jaki jest cel, sens jego istnienia, nie mówiąc już nawet o pytaniach dotyczących rzeczywistości jego bytu, wewnętrznej struktury i wszystkich zewnętrznych uwarunkowań; tego, co jest w nim niezmienne oraz względne, przypadłościowe. Polaryzowanie się, w związku z tym, kierunków bardziej spirytualistycznych i materialistycznych - zarzucających sobie nawzajem

32 U. Hannerz, Powiazania transnarodowe, s. 41; R. Linton, Kulturowe podstawy osobowości, tłum. A. Jasińska-Kania, Warszawa 2000, s. 5-18. 
niewystarczalność stosowanych metod i kruchość narzędzi, jakimi posługują się w ich ramach - jest drugorzędne ${ }^{34}$.

Stajemy więc wobec bardzo poważnego dylematu. Albo pogodzimy się ze stanem rozwarstwienia wiedzy o człowieku, co nie daje żadnej nadziei na pokonanie wspomnianej bezradności, albo zdecydujemy się jednak na próbę poszukania jakiejś płaszczyzny, mogącej stanowić podstawę wielu kierunków, może nawet niewykluczającej dotarcia do syntezy. Zwłaszcza, że takie próby pojawiały się już wielokrotnie, także w Polsce, choć $z$ kontynuacją ich, a nawet akceptacją, bywało bardzo różnie. W tym jednak celu nie unikniemy dość radykalnego wyboru, narażonego oczywiście na krytykę i kontestację. Czy obawa lub chęć uniknięcia tychże jest wystarczającym powodem zaniechania zmierzenia się z lansowaną tendencją, coraz wyraźniej ukazującą się jako bardzo groźna. Wybór taki - jak się wydaje - powinien być uwarunkowany otwarciem na owe dwie kwestie, z którymi współczesne dziedziny wiedzy o człowieku kompletnie sobie nie radzą i dlatego znajdują się w coraz głębszym kryzysie, niezależnie od swoich osiągnięć i nowych propozycji. Chodzi naturalnie o tajemnicę i prawdę; o zdobywanie wiedzy o człowieku, z którego nie wyrzuca się problemu prawdy i któremu nie przeszkadza obecność wymiaru tajemnicy.

Decydując się na rozstrzygnięcie niestarające się wpisać w przyjęty nurt, niespecjalnie liczący się z tradycją, sięgnijmy do historii. Otóż okazuje się, że obecne rozproszenie, a nawet rozrywanie rzeczywistości ludzkiej przez różne dyscypliny, konkurujące ze sobą i często wzajemnie próbujące się dyskredytować oraz wykluczać, nie jest czymś radykalnie nowym. Źródła kultury europejskiej oraz koncepcja człowieka, znajdujące się u podstaw naszej cywilizacji, są różnorodne. Zaliczyć trzeba do nich starożytną Grecję oraz Rzym, wkład ludów celtyckich, germańskich, słowiańskich, ugrofińskich, kulturę judaistyczną oraz muzułmańską ${ }^{35}$. Wszystkie te tradycje mogły się kiedyś spotkać, a nawet ewoluować w jeden system - program, niepoddający się dominującej dziś destrukcji. Mimo wielu trudności mogła się pojawić „filozofia umiaru”, nie ze względu na zarzucanie wszelkiej specjalizacji, szczegółowej wiedzy, ale na obecne w niej miejsce - na właściwym jej poziomie wiedzy - zarówno dla zewnętrznego, materialnego świata, jak i człowieka, który dostrzegając swoją zależność nie pozwalał się do niego tylko bez reszty sprowadzićc ${ }^{36}$. Przypomnijmy, że nazywano ją „przewrotem Kopernikańskim w dziedzinie ludzkiej myśli”, właśnie ze względu na potwierdzaną w doczesności - w naturze, wyjątkowość

\footnotetext{
34 A. Salamucha, Natura czy kultura? Wstępna charakterystyka sporu, s. 74.

35 Jan Paweł II, Ecclesia in Europa, Rzym 2003, 19.

36 E. Sienkiewicz, Koncepcja „rewolucji wspólnotowej” w polskiej teologii uczestnictwa, Poznań 2003, s. 58.
} 
i niepowtarzalność ludzkiego bytu ${ }^{37}$. Ponad całe stworzenie człowiek wyrasta jako osoba (termin ten zupełnie znika z współczesnych szczegółowych dyscyplin zajmujących się człowiekiem). Chodzi o ,aspekt”, który nie konkuruje z naturą; nie podważa jej, ani nie umniejsza, ale właśnie szczególnie podkreśla przez to, że do niej należy. Człowiek jako osoba jest sam dla siebie jedynym i niepowtarzalnym światem, ale i wchodzącym w relację z drugimi, przez co najbardziej się potwierdza, rozwija i spełnia. Tworzy nie tylko struktury społeczne ${ }^{38}$, poza człowiekiem w całej naturze nieobecne - wbrew temu, co twierdzi chociażby wspominany E. Wilson - ponieważ ich podstawowy wyznacznik, czyli cel, w oparciu tylko o biologiczne kryteria, jest trudny do ukazania. Człowiek tworzy także wspólnoty, czyli takie relacje, które na poziomie struktur społecznych są niedostępne. Poza tym dowartościowujący naturę, która w osobie ludzkiej przestaje być czymś podzielonym między człowiekiem i otaczającym go światem - przyrodą, jak również czymś zrównującym bez reszty przyrodę i człowieka. Dzięki swojej osobowej podstawie złożenia, które w nim jest, człowiek zwracając się do tego, co na zewnątrz, nadaje temuż sens, właśnie ze względu na swoją naturalną złożoność, niepowtarzalność. Usensawiając niejako naturę, sam się rozwija, doskonali, przez rozwijanie i doskonalenie swojej wewnętrznej, stanowiącej o osobie struktury ${ }^{39}$. I nie przeszkadza temuż znajdująca się w nim bytowa szczelina - otwartość nie tylko na drugich, na świat innych osób, ale na transcendencję, co tylko tę otwartość na Osobę potwierdza. W tej samej mierze, $w$ jakiej potwierdza istnienie tajemnicy i potrzebę poznania prawdy.

Nie chodzi również o przezwyciężenie dwuwarstwowej struktury bytu ludzkiego: zewnętrznej, którą stanowi biologiczny, cielesny i poddający się zewnętrznemu doświadczeniu wymiar bytu ludzkiego oraz wewnętrznej, duchowej $^{40}$. Elementarne doświadczenie człowieka potwierdza nie tylko świadomościowy, subiektywny wymiar tegoż, ale i jego charakter przedmiotowy; obecność w doświadczeniu rzeczywistości istniejącej realnie oraz niezależnie od poznającego oraz przeżywającego podmiotu ${ }^{41}$. Ontyczna wyjątkowość i zarazem niepowtarzalność bytu ludzkiego, pozwalająca odróżniać w nim jego osobiste, świadomie podejmowane działanie od tego, co dzieje się w człowieku, nie pozwala ani sprowadzać jakichkolwiek wytworów człowieka do natury, ani też

37 K. Jeżowski, Stefan Kardynał Wyszyński. Myśl narodowa i państwowa. Człowiek - rodzina - kultura - naród, Kraków 1999, s. 43-44.

38 Ibidem, s. 46-47.

39 S. Wyszyński, Duch pracy ludzkiej. Konferencje o pracy, Poznań 1957, s. 25-33.

40 J.Galarowicz, Człowiekjest osoba. Podstawy antropologiifilozoficznej Karola Wojtyty, Kraków 1994, s 29.

41 K. Wojtyła, Problem doświadczenia w etyce, w: W nurcie zagadnień posoborowych, t. 3, B. Bejze, (red.), Warszawa 1969, s. 219. 
ich przeciwko naturze zwracać (podporządkowywać kulturę naturze i odwrotnie). Umożliwia bowiem odnoszenie się natury właśnie do tego, co dzieje się w człowieku i odnalezienie się podmiotu wszelkich ludzkich działań właśnie w ludzkiej naturze ${ }^{42}$. W ten sposób natura jest podstawą istotowej spójności w człowieku, który mimo swojego zanurzenia w materii, nie traci własnej podmiotowości. Wręcz ją przez to potwierdza dzięki jedynej w swoim rodzaju złożoności bytu ludzkiego. To ona decyduje o tym, że osoba nie przestaje być „niewypowiedzianą tajemnicą”, ponieważ misterium podmiotu wykracza poza naturę ludzką, która sama w sobie nie posiada samoistności bytowej. Dlatego zakorzeniony w rzeczywistości byt duchowy jest otwarty, transcendentny wobec tego, co się w nim dzieje, również względem samego działania. I choć zasadza się na tym, co pozwala się ująć, zbadać i dokładnie opisać, sam w sobie jest niedefiniowalny ${ }^{43}$.Zdaje sobie sprawę i doświadcza szczególnego mechanizmu, dziania się w nim, przebiegu wielu procesów, które posiadają swoją podstawę ontyczną - suppositum. I nawet jeśli nad wieloma z nich nie potrafi zapanować, to - chociażby przez doświadczenie swojego wolnego działania - w nich tylko się nie wyczerpuje, co jest też najgłębszą racją ludzkiej natury ${ }^{44}$.

Znajomość historii może się więc okazać pożyteczna i nie tylko dlatego, że dzięki niej nie będziemy popełniać tych samych błędów. Również po to, aby dzięki niej daną rzeczywistość najlepiej rozumieć, właśnie przez jej dzieje, w których dostrzegamy wyjątkową realność, sens i dynamikę istnienia oraz wewnętrzną strukturę osobową. Człowieka trzeba poznawać i rozumieć poprzez jego genezę, początki - na ile udaje się nam do nich dziś dotrzeć ${ }^{45}$. Na pytanie o człowieka trudno będzie odpowiedzieć zatrzymując się na poziomie teorii poznania i metodologii, co jest jedynie maleńkim wycinkiem tej rzeczywistości, jaką jest osoba ludzka ${ }^{46}$. Najlepszym dowodem na to jest „naukowa bezradność” wielu współczesnych uczonych, zajmujących się człowiekiem. Ograniczając się do metodologicznych założeń, proponują oni z reguły skrajne i minimalistyczne ujęcia bytu osobowego, w najlepszym przypadku starając się jakoś pogodzić ze sobą to, co ujmowali jako odrębne fragmenty ${ }^{47}$. Pogłębiają tym samym kryzys, którego istotę i skutki staraliśmy się powyżej zauważyć. Podobnie jak to, że najlepszym rozwiązaniem sporu o rozumienie natury i kultury jest personalizm.

\footnotetext{
$42 \quad$ Ibidem, s. 119.

43 Cz. S. Bartnik, Personalizm teologiczny wedlug Kardynała Karola Wojtyly, „Zeszyty Naukowe KUL" 1-3 (1979), s. 52-53.

44 Cz. S. Bartnik, Personalizm, Lublin 1995, s. 256.

$45 \quad$ Ibidem, s. 39.

46 M. Gogacz, Wokót problemu osoby, Warszawa 1974, s. 28 i 194.

47 Cz. S. Bartnik, Ewangelia a rewolucja, „Chrześcijanin a Współczesność”, 4 (1989), s. 7.
} 
I to personalizm chrześcijański, który może, a nawet powinien być najlepszym wyznacznikiem lub kluczem interpretacyjnym $\mathrm{w}$ podstawowym problemie tego artykułu. Tak jak najlepszym kryterium jest antropologia chrześcijańska. Odwołująca się - w całym bogactwie rozwiązań i doświadczeń w patrzeniu na człowieka, próbach opisywania go, a zwłaszcza definiowania - do tego jednego wydarzenia, przyćmiewającego wszystkie inne i decydującego o całkowicie innym patrzeniu na człowieka, na jego możliwości oraz charakterystyczne cechy, władze. Chodzi oczywiście o fakt Wcielenia Słowa ${ }^{48}$.

\section{Zagadnienie prawdy $\mathrm{w}$ relacji natury i kultury}

Wydarzenie Wcielenia rzuca bowiem nowe światło na naturę i kulturę człowieka. Nie wchodzimy w tym miejscu zbyt głęboko w kwestie teologiczne, choć nie są one bez znaczenia i dlatego nie wolno ich całkowicie pomijać. Odnosząc się do natury, a właściwie do natur Słowa, nie wolno przeoczyć, że podstawą ich zjednoczenia jest Osoba. W tym sensie to nowe, rzucone na rzeczywistość natury światło, pokazuje nam, że właśnie osoba jest szczególnym „miejscem” nie tylko właściwego rozumienia natury, ale również możliwości poznania jej; wnikania w jej strukturę, której także - jak dotąd - nie udało się całkowicie uwolnić z okrywającego ją wymiaru tajemnicy. Pojawiają się jednak bardzo konkretne pytania i wątpliwości: co w związku z tym z kulturą? Czy jest to wystarczającym usprawiedliwieniem - nie zapominając o wszystkich wzmiankowanych powyżej uwagach - antropocentryzmu? Zwłaszcza, że szybko może się pojawić jeszcze poważniejszy zarzut, tym razem nawet o arogancję. Syn mówi jednak wyraźnie: „Ja jestem prawdą” (J 14, 6). Potwierdza to także Duch Prawdy, który przychodzi prawdy nauczyć i wszystko, co istotne przypomnieć (J 14, 26), dając wszystkim język jedności, realizującej się w wielości. Nie usuwa przy tym, ani nie marginalizuje innych języków i doświadczeń ludzkich; innych, choćby mniej znanych kultur. Nie podporządkowuje jednych drugim, ponieważ w nich wszystkich jest obecna i harmonizuje je, prawda. Jest ona nie do pominięcia ${ }^{49}$, jak nie do pominięcia jest człowiek, choć nie można powiedzieć, że nie ma takich prób. Owszem, toczy się wręcz prawdziwa batalia i dlatego dziś mamy taki problem z kulturą; nie mniejszy - jak się okazuje - z naturą i przede wszystkim $z$ tożsamością.

48 Jan Paweł II, Redemptor hominis, Rzym 1979, 11; idem, Wierze w Chrystusa Odkupiciela, Warszawa 1991, s. 189; idem, Ecclesia in Europa, Rzym 2003, 25; idem, Europa jutra. Jana Pawła II wizja Europy, A. Sujka (wyb. i oprac.), Kraków 2000.

49 M. Fiedrowicz, Apologie im frühen Christentum. Die Kontroverse um den christlichen Wahrheitsanspruch in der ersten Jahrhunderten, Paderborn 2001, s. 227-315. 
Człowiek w sporze o rozumienie natury i kultury musi się zdobyć na przygodę z prawdą - o sobie i o świecie ${ }^{50}$. Tylko tak może rozwiązać ten spór i uniknąć ostrego konfliktu, w którym sam będzie najbardziej zagrożony. Wszystko, co tworzy (kultura), nie zmienia, a tym bardziej nie stwarza nowej natury. Jedynie ją uszlachetnia, udoskonala, przy poszanowaniu tego, co fundamentalne, niezmienne i właściwie umożliwiające tworzenie (działalność kulturalną) ${ }^{51}$. Odejście od tego - od prawdy o człowieku: kim jest i jakie są jego ograniczenia, ale i możliwości - nie może być rozumiane jako tylko odejście od dawnego i już nieaktualnego obrazu człowieka. W gruncie rzeczy chodzi tu o próbę zanegowania tego, od czego wszelkie poprawne rozumienie jest zależne i co trzeba traktować jako kryterium tego rozumienia. Czego dalej żaden podmiot w sobie tylko, na mocy swojej natury, nie odnajduje i nie wytwarza, jak jakiegokolwiek dobra. Co niejako przychodzi do niego z zewnątrz (w Jezusie Chrystusie; Duchu Świętym) i co może być przyjęte tylko dlatego, że człowiek jest taki jaki jest (w taki właśnie sposób stworzony). Kulturotwórcza bowiem działalność człowieka jest realizacją możliwości zawartych w naturze ludzkiej. Przy czym chodzi o wolne działanie, a nie zdeterminowane biologicznie ${ }^{52}$. Pogląd na naturę bytu ludzkiego, jego możliwości, będzie rzutował zatem na rozumienie kultury. Człowiek jest nie tylko twórcą kultury, ale również jej sensem, celem. Stąd prymat „być” nie tylko przed „mieć”, ale w równej mierze także przed „działać”, „czynić”.

Joseph Ratzinger pisząc swego czasu na temat inkulturacji, zakładał tę samą istotę każdego człowieka i tkwiącą w niej wspólną prawdę człowieczeństwa, służącą budowaniu jedności. Innymi słowy, poważna rozmowa na temat kultury nie jest możliwa przy pominięciu tej najgłębszej, fundamentalnej prawdy o człowieku. Można to nazwać nawet antropocentryzmem, ale bez rozwiązania problemu człowieka, nie uda się skutecznie rozwiązać kwestii związanych z kulturą. ,Kultura - według niemieckiego teologa - jest wyrosłą w procesie rozwoju historycznego wspólnotową formą wyrazu wyników poznania i wartości, które kształtują życie określonej wspólnoty” ${ }^{53}$. Zdaniem Ratzingera „każda kultura

50 Rozmaite zabiegi w celu osłabienia takiego dążenia, a nawet wyeliminowania go są podejmowane z zaangażowaniem równie wielkim, jak wielkie znaczenie dla człowieka posiada prawda. To nie tylko paradoks, to jakiś nowy etap w długiej i starej jak świat oraz człowiek walce dobra ze złem. J. Pieper, Was heisst Interpretation?, w: idem, Schriften zum Philosophiebegriff, Hamburg 1995, s. 226n.

51 Jan Paweł II, Fides et ratio, Rzym 1998, 70.

52 L. Dyczewski, Kultura - aspekt teologiczny, w: Encyklopedia katolicka, t. X, A. Szostek (red.), Lublin 2004, k. 190.

53 J. Ratzinger, Wiara - prawda - tolerancja. Chrześcijaństwo a religie świata, s. 49-50. 
jest ostatecznie oczekiwaniem na prawdę"54. Trzeba zatem najpierw poszukać odpowiedzi na pytanie kim człowiek jest i co powinien zrobić ze swoim człowieczeństwem? Kultury otwierają się na siebie, spotykają tylko na tej podstawie - jedynej, wszystkich zobowiązującej prawdy o człowieku. Ale my właśnie mamy największy problem z prawdą obiektywną, którą wszyscy chcieliby uznać za obowiązującą. Odnosi się to również do przekonania Hansa Kelsena, według którego prawdę zastępuje decyzja większości ${ }^{55}$, ponieważ ona jako niebędąca prawdą, a tylko zwykłym kompromisem, nie ma mocy zobowiązującej. Bardziej trafne jest określenie, że coraz częściej praktyka zastępuje prawdę ${ }^{56}$. Nie wynika bowiem z natury - odnośnie do powyższych rozstrzygnięć. Konflikt prawd prowadzi nieuchronnie do konfliktu kultur ${ }^{57}$. Jedna zaczyna zagrażać drugiej, usuwać ją lub wchłaniać, a nawet niszczyć, bo zniesiona została płaszczyzna porozumienia - podstawa jedności, czyli obiektywna prawda. Tu leży prawdziwy problem, a przedstawianie go - zresztą nie od dziś - jako konfliktu kultury z naturą jest nieporozumieniem, powstałym $z$ wypchnięcia (odsunięcia) problemu z człowieka - jego natury i kultury na poziom, na którym spór ten nie może być rozwiązany, gdyż nie dotyczy istoty ludzkiego bytu. Innymi słowy, zawsze chodzi o naturę i kulturę człowieka, a nie o rozumienie kultury i natury jako pretekst do pominięcia problemu człowieka, a przynajmniej zwolnienia się $z$ trudnego sporu o jedyną, wszystkich zobowiązującą prawdę.

Czy można się zatem dziwić, że pozbywając się prawdy postmodernistyczne społeczeństwa, hołdujące relatywizmowi, chcą się uporać także z naturą. Jeśli rozumiemy ją jako pewne zdeterminowanie człowieka, a przynajmniej podstawę do wskazywania w nim elementów stałych, niezmiennych, to całkiem „naturalne” wydaje się, gloryfikowanie kultury kosztem natury. Oczywiście swoiście rozumianych, w oderwaniu od głębszej tradycji, ponieważ ona także podkreśla ciągłość i trwałość. Ta jednak może się okazać bardzo pomocna, choćby ze względu na przechowywaną w niej pamięć o tym, że prawda w tym znaczeniu (wiązana z Objawieniem przez Syna) nigdy nie była czymś oczywistym, a przynajmniej bezspornym. I tak, dla Greków np. była ona głupstwem, wobec wyżyn własnej kultury. A przenikanie się przez całe pokolenia nie było

$\overline{54 \quad \text { Ibidem, s. } 55 .}$

55 V. Possenti, Le società liberali al bivio. Lineamenti di filosofia della società. Marietti 1991, s. 315-345; W. Waldstein, Teoria generale del diritto, Roma 2001.

56 J. Ratzinger, Wiara - prawda - tolerancja. Chrześcijaństwo a religie świata, s. 59.

57 J. Dupuis, The Kingdom of God and World Religions, , Journal of Theological Reflection” 51 (1987), s. 530-544; idem, Verso una teologia cristiana del pluralismo religioso, Brescia 1997; C. Gnilka, La conversione della cultura antica vista dai Padri della Chiesa, „Cristianesimo nella storia" II (1990), s. 503-615; idem, Die Methode der Kirchenväter im Umgang mit der antiken Kultur, t. 2, Kultur und Conversion, Basel 1993. 
czymś ani łatwym, ani oczywistym, o czym świadczą znane z historii kontrowersje $^{58}$. Przenikanie się, którego dobrym przykładem jest dzieło św. Augustyna, z rozbudzonymi przez lekturę Hortensjusza Cycerona pragnieniami i ich zaspokojeniem dzięki lekturze Biblii, początkowo ocenianej przez sławnego retora z Tagasty jako wyjątkowo barbarzyńska. Chrześcijaństwo i związana $z$ nim prawda nigdy nie są czymś wyłącznie własnym, ale czymś przychodzącym $z$ zewnątrz (Abraham zostawia swój dom i wychodzi - Rdz 12, 1-8). Spotyka nas coś - ktoś, a nie tylko uświadomiona nasza zdolność sama z siebie. Człowiek w tym sensie jest „pielgrzymem prawdy” (do prawdy) ${ }^{59}$. Poza tym dobrze jest pamiętać, że kultura helleńska nie zadowalała się mitologicznymi obrazami, ani swoimi cywilizacyjnymi osiągnięciami, o czym nieco zapominamy, lecz stawiała wyraźne pytanie o prawdę. Tym bardziej Biblia, która chce skonfrontować człowieka z prawdą, z której wprost bije przekonanie, że człowiek jest zdolny poznać prawdę - choć nie jest to proste - i posługuje się w tym celu kluczem chrystologicznym ${ }^{60}$.

Człowiek otwierając się na prawdę, przychodzącą do niego niejako z zewnątrz, musi mieć również odwagę wejścia w wymiar tajemnicy. Podobnie jak prawda także od niego niezależna, ponieważ na pewno wciąż więcej jest szlaków przez człowieka jeszcze nierozpoznanych, niż dróg, które zdążył już dobrze wydeptać i zna na nich prawie każdy kamień; każde wzniesienie i każdy dół.

Słowa klucze: natura, kultura, prawda, człowiek, osoba, tajemnica, naturalizm, idealizm, personalizm, antropocentryzm, biologiczny redukcjonizm, postmodernizm, cywilizacja, gatunek, przyroda, tożsamość.

\section{Bibliografia:}

1. Bartnik Cz. S., Ewangelia a rewolucja, „Chrześcijanin a Współczesność”, 4 (1989).

2. Bartnik Cz. S., Personalizm, Lublin 1995.

3. Bartnik Cz. S., Personalizm teologiczny wedlug Kardynata Karola Wojtyly, „Zeszyty Naukowe KUL" 1-3 (1979).

4. Bednarski J., Enkulturacja, w: Stownik etnologiczny, Z. Staszczak (red.), Warszawa - Poznań 1987.

58 J. Sobrino, La fe en Jesucristo. Ensayo desde las victimas, San Salvador 1999, s. 437-465; A. Schenker, L' Écriture sainte subsiste en plusieurs formes canoniques simultanés, w: Interpretazione della Bibbia nella Chiesa. Atti del Simposio promosso dalla Congregazione per la dottrina della fede, Città del Vaticano 2001, s. 178-186; J. Wohlmuth, Die Tora spricht die Sprache der Menschen, Paderborn 2002, s. 28-35.

59 J. Ratzinger, Wiara - prawda - tolerancja. Chrześcijaństwo a religie świata, s. 71-74.

60 Ibidem, s. 74-78. 
5. Burszta W. J., Antropologia kultury, Poznań 1998.

6. Dłubacz W., Natura czy naturalizm?, w: Substancja, natura, prawo naturalne, Lublin 2006.

7. Dupuis J., The Kingdom of God and World Religions, „Journal of Theological Reflection" 51 (1987).

8. Dupuis J., Verso una teologia cristiana del pluralismo religioso, Brescia 1997.

9. Dyczewski L., Kultura - aspekt teologiczny, w: Encyklopedia katolicka, t. X, A. Szostek (red.), Lublin 2004.

10. Fiedrowicz M., Apologie im frühen Christentum. Die Kontroverse um den christlichen Wahrheitsanspruch in der ersten Jahrhunderten, Paderborn 2001.

11. Gajda J., Antropologia kulturowa, cz. I, w: Wprowadzenie do wiedzy o kulturze, Toruń 2003.

12. Galarowicz J., Człowiek jest osoba. Podstawy antropologii filozoficznej Karola Wojtyty, Kraków 1994.

13. Gnilka C., Die Methode der Kirchenväter im Umgang mit der antiken Kultur, t. 2, Kultur und Conversion, Basel 1993.

14. Gnilka C., La conversione della cultura antica vista dai Padri della Chiesa, „Cristianesimo nella storia" II (1990).

15. Gogacz M., Wokót problemu osoby, Warszawa 1974.

16. Grzegorczyk A., Psychiczna osobliwość człowieka, Warszawa 2003.

17. Hajduk Z., Natura, w: Encyklopedia katolicka, t. XIII, E. Gigilewicz (red.), Lublin 2009

18. Hall E. T., Poza kultura, Warszawa 1984.

19. Hannerz U., Powiazania transnarodowe. Kultura, ludzie, miejsca, tłum. K. Franek, Kraków 1996.

20. Harris L., Kosmopolityczne złudzenie, tłum. A. Romaniuk, „Res Publica” 3 (2006).

21. Horbowski A., Edukacja kulturalna jako system działań społeczno-wychowawczych, Rzeszów 2000.

22. Jan Paweł II, Ecclesia in Europa, Rzym 2003.

23. Jan Paweł II, Europa jutra. Jana Pawła II wizja Europy, A. Sujka (wybór i oprac.), Kraków 2000.

24. Jan Paweł II, Fides et ratio, Rzym 1998.

25. Jan Paweł II, Redemptor hominis, Rzym 1979.

26. Jan Paweł II, Wierze w Chrystusa Odkupiciela, Warszawa 1991.

27. Jeżowski K., Stefan Kardynat Wyszyński. Myśl narodowa i państwowa. Człowiek rodzina - kultura - naród, Kraków 1999.

28. Kowalczyk S., Kultura a religia, w: Encyklopedia katolicka, t. X, A. Szostek (red.), Lublin 2004.

29. Kowalczyk S., Kultura - pojęcie, w: Encyklopedia katolicka, t. X, A. Szostek (red.), Lublin 2004.

30. Kowalski J., Kultura w integralnym rozwoju człowieka w świetle nauczania Jana Pawła II, w: Stużyć prawdzie i miłości, J. Kowalski (red.), Częstochowa 1984.

31. Kozielecki J., Transgresja i kultura, Warszawa 1997.

32. Linton R., Kulturowe podstawy osobowości, tłum. A. Jasińska-Kania, Warszawa 2000 . 
33. Nikitorowicz J., Globalizacja a kultura jednostki, w: Kultury tradycyjne a kultura globalna. Konteksty edukacji międzykulturowej, t. 1, J. Nikitorowicz (red.), Białystok 2001.

34. Nussbaum M., Patriotism and Cosmopolitanism, „Boston Review” 19/5 (1994).

35. Oniszczenko W., Genetyczne podstawy ludzkich zachowań. Przeglad badań w populacji polskiej, Gdańsk 2005.

36. Pieper J., Was heisst Interpretation?, w: J. Pieper, Schriften zum Philosophiebegriff, Hamburg 1995.

37. Platon, Państwo, tłum. W. Witwicki, Kęty 2003.

38. Popkin R. H., Stroll A., Filozofia, tłum. J. Karłowski, N. Leśniewski, A. Przyłęcki, Poznań 1994.

39. Posern-Zieliński A., Akulturacja, w: Stownik etnologiczny, Z. Staszczak (red.), Warszawa - Poznań 1987.

40. Possenti V., Le società liberali al bivio. Lineamenti di filosofia della società. Marietti 1991.

41. Ratzinger J., Wiara - prawda - tolerancja. Chrześcijaństwo a religie świata, tłum. R. Zajączkowski, Kielce 2004.

42. Reroń T., Kultura, w: Leksykon duchowości katolickiej, M. Chmielewski (red.), Kraków 2002.

43. Ridley M., Nature via Nurture (Genes, experience and what makes us human, London 2003.

44. Rogowski R., Wiara a kultura w aspekcie antropologiczno-teologicznym, „Homo Dei" 79 (1980), 3.

45. Salamucha A., Natura czy kultura? Wstępna charakterystyka sporu, w: Kultura wspótczesna a wychowanie człowieka, D. Kubinowski (red.), Lublin 2006.

46. Schenker A., L'Écriture sainte subsiste en plusieurs formes canoniques simultanés, w: Interpretazione della Bibbia nella Chiesa. Atti del Simposio promosso dalla Congregazione per la dottrina della fede, Città del Vaticano 2001.

47. Sienkiewicz E., Koncepcja „rewolucji wspólnotowej” w polskiej teologii uczestnictwa, Poznań 2003.

48. Singer P., Etyka praktyczna, tłum. A. Sagan, Warszawa 2003.

49. Singer P., O życiu i śmierci. Upadek etyki tradycyjnej, tłum. A. Alichniewicz, A. Szczęsna, Warszawa 1997.

50. Singer P., Wyzwolenie zwierzat, tłum. A. Alichniewicz, A. Szczęsna, Warszawa 2004.

51. Skoczyński J., Kultura, w: Stownik społeczny, B. Szlachta (red.), Kraków 2004.

52. Sobrino J., La fe en Jesucristo. Ensayo desde las victimas, San Salvador 1999.

53. Suchodolski B., Kim jest czlowiek, Warszawa 1985.

54. Szacka B., Stowo wstępne, w: E. O. Wilson, O naturze ludzkiej, Warszawa 1987.

55. Szopski M., Komunikowanie międzykulturowe, Warszawa 2005.

56. Waldstein W., Teoria generale del diritto, Roma 2001.

57. Wilson E. O., Konsiliencja. Jedność wiedzy, Poznań 2002.

58. Wilson E. O., Socjobiologia, Poznań 2000.

59. Wohlmuth J., Die Tora spricht die Sprache der Menschen, Paderborn 2002.

60. Wojnar I., Humanistyczne intencje edukacji, Warszawa 2000. 
61. Wojtyła K., Problem doświadczenia w etyce, w: W nurcie zagadnień posoborowych, t. 3, B. Bejze, (red.), Warszawa 1969.

62. Wolański N., Uniwersalizm jako podstawa cywilizacji europejskiej. Biologiczne i cywilizacyjne aspekty uniwersalizmu, „Społeczeństwo Otwarte” 5 (1998).

63. Wosińska W., Oblicza globalizacji, Sopot 2008.

64. Woźniak O., Dlaczego niektórzy ludzie odnosza sukces częściej niż inni?, „Przekrój Nauki” 1 (2008).

65. Wyszyński S., Duch pracy ludzkiej. Konferencje o pracy, Poznań 1957. 